\title{
PENGARUH MOTIVASI TERHADAP KEPUASAN KERJA PADA KARYAWAN KPRI "PERTAGUMA" KOTA MADIUN
}

\author{
Devie Putri Wijayanti \\ Mahasisiwa Program Studi Pendidikan Ekonomi IKIP PGRI MADIUN
}

\begin{abstract}
This study aims to (1) To know the motivation of employees KPRI "Pertaguma" Madiun, (2) To know employee job satisfaction on KPRI "Pertaguma" Madiun, and (3) To know the motivation is there any influence on job satisfaction in employees KPRI "Pertaguma" Madiun. The samples in this study using a sample that is saturated cooperative employee is 17. Data collection using interviews and questionnaires. Data analysed use simple linear regression statistical methods, and to test whether or not valid instrument used regression methods. The results showed that motivation has a positive influence on employee job satisfaction on KPRI "Pertaguma" Madiun. It is derived from the value of Fisher's exact test, whereas the $\mathrm{F}_{\text {count }}$ value of $64,792 \mathrm{~F}_{\text {tabel }}$ value of 4,54. On the other hand $\operatorname{Sig}_{\text {hit }}$ known values of 0.000 and 0.05 known Sig $_{\text {prob }}$ value. This means that the $F_{\text {value }} \geq F_{\text {tabel }}(64.792 \geq 4.54)$ or $\operatorname{Sig}_{\text {hit }} \leq \operatorname{Sig}_{\text {prob }}(0.05 \leq 0.000)$. Meaning a rejection of $H_{0}$ which shows that there is an influence of motivation on job satisfaction in employees KPRI "Pertaguma" Madiun. In addition to the values obtained with the $t, t_{\text {test }}$ value is 8.049 while the value $t_{\text {table }} 2,131$. On the other hand $\operatorname{Sig}_{\text {hit }}$ value of 0.000 and Sig ${ }_{\text {prob }}$ value as 0.05 . This means that $t \geq t_{\text {table }}$ (8.049 $\left.\geq 2.131\right)$ or $\leq \operatorname{Sig}_{\text {hit }} \operatorname{Sig}_{\text {prob }}(0.05 \leq 0.000)$. It means that $\mathrm{H}_{0}$ is rejected, meaning that motivation has a different effect on employee job satisfaction on KPRI “Pertaguma” Madiun.
\end{abstract}

Keys words: motivation, job satisfaction

\section{PENDAHULUAN}

Di era yang serba instan saat ini, manusia dituntut untuk mencapai kehidupan yang layak. Sehingga manusia mencari cara dan memikirkan usaha apa yang dilakukan untuk mencapai tujuan yang diharapkannya. Untuk masalah bekerja atau memulai usaha pastinya tidak instan pula. Mereka harus mencari pekerjaan atau membuat usaha yang baru.

Didalam kegiatan dunia usaha di Indonesia, kita mengenal berbagai macam bentuk badan hukum perusahaan yaitu: Badan Usaha Milik Daerah, Perseroan Terbatas, Perusahaan Perseorangan, Persekutuan, Persekutuan dengan Firma, Badan Usaha Milik Negara, Persekutuan Komanditer, dan Koperasi.

Bentuk-bentuk kegiatan usaha, dikelompokkan menjadi, Usaha Swasta, Usaha Pemerintah dan Koperasi. Tetapi tidak semua negara didunia ini mengelompokkan kegiatan-kegiatan usaha tersebut dalam 3 sektor, seperti halnya yang dilakukan di negara Indonesia. Dibanyak negara, umumnya hanya ada 2 usaha saja yaitu, usaha yang diselenggarakan oleh swasta dan yang diusahakan oleh pemerintah. Koperasi pada umumnya dikelompokkan dalam usaha swasta. (Hendrojogi, 2007: 273) 
Kegiatan dalam koperasi itu sendiri sangat penting dalam pemenuhan kebutuhan manusia, apalagi dengan membentuk KPRI (Koperasi Pegawai Republik Indonesia) setidaknya setiap pegawai negeri dianjurkan untuk membentuk atau mendirikan koperasi.

Kelancaran dan keberhasilan KPRI tidak hanya karena anggotanya sendiri tetapi tentu ada faktor yang mendukung yang lain misalnya saja karyawan dan pengurus. Pengurus, yang telah terpilih dalam rapat anggota menerima pelimpahan wewenang dari anggota untuk mewakili anggota-anggota dalam pengelolaan koperasi dan harus mampu menjalankan kewajibannya secara bijak dan melindungi kepentingan anggotanya.

Dengan demikian pengurus merasakan puas dalam bekerja. Tentunya kepuasan dalam bekerja tersebut tidak terjadi secara terus menerus, bagaimana cara untuk memecahkan permasalahan yang ada di KPRI ini dapat mereka atasi. Ambar Teguh Sulistiyani \& Rosidah (2003: 191) menyatakan: "Kepuasan kerja tampaknya dapat mempengaruhi kehadiran seseorang dalam dunia kerja, dan ingin melakukan perubahan kerja, yang selanjutnya juga berpengaruh terhadap kemauan untuk bekerja”. Pengurus maupun atasan mereka bisa memotivasi, agar mereka selalu senantiasa bekerja dengan rasa yang nyaman dan giat dalam bekerja.

Menurut teori Herzberg (dalam Marihot Amh Manullang, 2006: 178), faktor-faktor yang berperan sebagai motivator terhadap pegawai, yakni yang mampu memuaskan dan mendorong orang untuk bekerja baik terdiri dari: achievement (keberhasilan pelaksanaan), recognition (pengakuan), the work it self (pekerjaan itu sendiri), responsibilities (tanggung jawab), advencement (pengembangan).

Apalagi keberhasilan pelaksanaan kegiatan dan pengembangan dalam koperasi diberikan sepenuhnya kepada pengurus, itu sering menimbulkan rasa ragu-ragu, tidak semangat dalam bekerja, takut salah, merasa bodoh, atau kondisi kerja yang menjenuhkan. Walaupun mereka digaji tapi mungkin berbeda karena pembagian tugas/pekerjaan mereka berbeda yang menyebabkan mereka merasa tidak puas. Ataupun kondisi "lingkungan kerja yang buruk, kotor, gelap, pengap, lembab, dan sebagainya akan menimbulkan cepat lelah dan menurunkan kreativitas”. (Edy Sutrisno, 2010: 119) Hal ini diperkuat dengan pendapat Edy Sutrisno (2010: 78) yang menyatakan bahwa "gaji lebih banyak menyebabkan ketidakpuasan, dan jarang orang mengekpresikan kepuasan kerjanya dengan sejumlah uang yang diperolehnya" yang dapat mempengaruhi emosi seseorang untuk mendapat pengakuan. "Pengakuan terhadap keberhasilan bawahan dapat dilakukan dengan berbagai cara" (Amirullah dan Rindyah Hanafi, 2002: 153) oleh atasan, dan motivasi dalam dirinya untuk dapat bekerja dengan maksimal dirasa kurang.

Apakah dengan adanya pengakuan dalam bekerja dari pimpinan karyawan bisa dikatakan puas, pastinya tidak hanya faktor diatas saja yang dapat memotivasi bawahannya dan dapat menimbulkan rasa kepuasan dalam bekerja. Pasti ada faktor lain yang dapat memotivasi, misalnya saja jam istirahat, kondisi kerja, lingkungan kerja, peralatan atau fasilitas yang menunjang dan peluang untuk berkembang.

Untuk menciptakan suatu kondisi demikian, maka diperlukan usaha yang dapat meningkatkan motivasi dan kepuasan kerja bagi setiap para pegawainya. Dan untuk itu diperlukannya penelitian, karena tujuan dari koperasi ini salah satunya adalah dapat meningkatkan kesejahteraan anggotanya, memotivasi karyawan supaya dapat bekerja semaksimal mungkin agar tetap menjaga kestabilan dalam bekerja, mencapai apa yang diinginkan dan dapat mencapai kepuasan kerja.

Untuk itu didirikannya KPRI "Pertaguma” di Kota Madiun pada tanggal 25 November 1963 ditempatnya yang terdahulu dan sekarang sudah menetap di Jl. Slamet Riyadi No. 81A Kota Madiun.

Dalam lingkungan kegiatan KPRI "Pertaguma” itu akan bermanfaat sekali bagi anggotanya karena dalam kegiatannya lebih 
mementingkan kegiatan usaha simpan pinjam, usaha swalayan dan persewaan mobil bagi anggotanya. Karena rata-rata penghasilan mereka juga tetap, maka masalah permodalan maupun simpan pinjam diharapkan bisa lancar.

"Motivasi berasal dari kata Latin movere yang berarti dorongan atau menggerakkan. Motivasi (motivation) dalam manajemen hanya ditunjukan pada sumber daya manusia umumnya dan bawahan khususnya”. (Malayu S.P Hasibuan, 2008: 141) Motivasi membahas tentang bagaimana caranya mengarahkan daya dan potensi yang ada pada bawahan, agar mau bekerja sama secara produktif berhasil mewujudkan tujuan yang telah ditentukan bersama.

"Motivasi dapat diartikan sebagai mengusahakan supaya seseorang dapat menyelesaikan pekerjaan dengan semangat karena ia ingin melaksanakannya”. (Terry, 2012: 130)

Dari beberapa pengertian motivasi diatas disimpulkan bahwa "motivasi adalah dari sesuatu yang menyebabkan dorongan atau pendorong semangat untuk bekerja”. Motivasi yang diberikan atasan terhadap bawahan sangat penting karena dapat meningkatkan kekuatan dan semangat untuk mendorong seseorang untuk bekerja dan mencapai hasil yang diinginkan secara optimal. Dan demikian motivasi dapat diartikan sebagai dorongan yang jadi dasar seseorang melakukan kegiatan, terutama apabila dorongan tersebut berasal dari dalam dirinya.

Adapun tujuan motivasi menurut (Malayu S.P Hasibuan, 2008: 146) antara lain sebagai berikut.

1) Meningkatkan moral dan kepuasan kerja karyawan.

2) Meningkatkan produktivitas kerja karyawan.

3) Mempertahankan kestabilan karyawan perusahaan.

4) Meningkatkan kedisiplinan karyawan.

5) Mengefektifkan pengadaan karyawan.

6) Menciptakan suasana dan hubungan kerja yang baik.

7) Meningkatkan loyalitas, kreativitas, dan partisipasi karyawan.
8) Meningkatkan tingkat kesejahteraan karyawan.

9) Mempertinggi rasa tanggung jawab karyawan terhadap tugas-tugasnya.

10) Meningkatkan efisiensi penggunaan alatalat dan bahan baku.

Sedangkan motivasi atau dorongan kepada karyawan untuk bersedia bekerja bersama demi tercapainya tujuan bersama ini menurut Indriyo Gitosudarmo dan Agus Mulyono (2001, 176) terdapat dua macam yaitu:

1) Motivasi finansial yaitu dorongan yang dilakukan dengan memberikan imbalan finansial kepada karyawan. Imbalan tersebut sering disebut insentif.

2) Motivasi nonfinanfial yaitu dorongan yang diwujudkan tidak dalam bentuk finansial/ uang, akan tetapi berupa hal-hal seperti pujian, penghargaan, pendekatan manusiawi dan lain sebagainya.

Dari tujuan diatas disimpulkan bahwa pemimpin harus mempunyai tujuan untuk memotivasi bawahannya seperti apa serta dapat meningkatkan kedisiplinan dan rasa tanggung jawab atas pekerjaannya. Setelah mengetahui tujuan tersebut maka karyawan akan terdorong untuk mewujudkan keinginan dirinya untuk lebih dihargai dan mendapatkan insentif atas kerja kerasnya.

Motivasi sebagian dari proses psikologi dalam diri seseorang yang dapat mempengaruhi oleh beberapa faktor. Menurut Edy Sutrisno (2010: 116) ada faktor-faktor yang dapat mempengaruhi motivasi adalah "faktor intern: (1) keinginan untuk dapat hidup, (2) keinginan untuk dapat memiliki, (3) keinginan untuk memperoleh penghargaan, (4) keinginan untuk memperoleh pengakuan, dan (5) keinginan untuk berkuasa. Sedangkan faktor ekstern meliputi: (1) kondisi lingkungan kerja, (2) kompensasi yang memadai, (3) supervisi yang baik, (4) adanya jaminan pekerjaan, (5) status dan tanggung jawab, dan (6) peraturan yang fleksibel”.

T. Hani Handoko (2011: 193) mengemukakan "Kepuasan kerja (job satisfaction) adalah keadaan emosional yang menyenangkan atau tidak menyenangkan dengan mana para 
karyawan memandang pekerjaan mereka”.

Wexley dan Yulk (2003) (dalam Wilson Bangun, 2012: 327) mengatakan bahwa "kepuasan kerja merupakan generalisasi sikapsikap terhadap pekerjaannya”.

"Kepuasan kerja adalah sikap emosional yang menyenangkan dan mencintai pekerjaannya”. (Malayu Hasibuan, 2008: 202)

Sedangkan Sondang Siagian (2000: 295) mengemukakan bahwa "Kepuasan kerja merupakan suatu cara pandang seseorang - baik yang bersifat positif maupun bersifat negatif tentang pekerjaannya”.

Berdasarkan dari uraian tersebut diatas dapat disimpulkan bahwa kepuasan kerja dapat mempengaruhi seseorang dalam menjalankan pekerjaannya, dan ingin melakukan perubahan kerja, yang seelanjutnya juga berpengaruh terhadap kemauan untuk bekerja. "Keinginan pegawai atau motivasi untuk bekerja biasanya ditunjukkan dengan dukungan aktivitas yang mengarah pada tujuan”. (Ambar dan Rosidah, 2003: 191)

Menurut Wexley dan Yulk (2003: 130) (dalam Wilson Bangun, 2012: 328), bahwa ada tiga teori tentang kepuasan kerja, antara lain: teori ketidaksesuaian (discrepancy theory), teori keadilan (equity theory), dan teori dua faktor (two factor theory).

Banyak faktor yang dapat mempengaruhi kepuasan kerja setiap orang untuk dapat bekerja sesuai dengan yang diharapkannya.

Gilmer (1996) (dalam Edy Sutrisno, 2010: 77) mengemukakan faktor-faktor yang mempengaruhi kepuasan kerja yaitu: "kesempatan untuk maju, keamanan kerja, gaji, perusahaan dan manajemen, pengawasan, faktor instrinsik dari pekerjaan, kondisi kerja, aspek sosial dalam pekerjaan, komunikasi, dan fasilitas".

Untuk mencapai tujuan dalam koperasi harus memperhatikan berbagai faktor yang mempengaruhi pencapaian suatu tujuan tersebut, di antaranya yaitu motivasi yang ada pada diri karyawan. Berkembangnya koperasi ditentukan oleh pengurus maupun karyawan yang mendapatkan motivasi dari atasannya. Agar dalam melaksanakan tugasnya mereka memiliki hal-hal yang bisa memotivasi mereka dalam bekerja.

Dalam hubungan dengan kepuasan kerja peranan motivasi sangatlah penting dalam rangka untuk daya penggerak dan meningkatkan kerja karyawan untuk memperoleh kepuasan kerja. Menurut Hasibuan (1999) (dalam Edy Sutrisno, 2010: 111) "motivasi adalah pemberian daya penggerak yang menciptakan kegairahan kerja seseorang, agar mereka mau bekerja sama, bekerja efektif, dan terintegrasi dengan segala daya upayanya untuk mecapai kepuasan”. Karena dengan apa saja yang diharapkan karyawan bisa tercapai dengan adanya dorongan semangat untuk bekerja.

\section{METODE PENELITIAN}

Dalam suatu rancangan penelitian harus menemukan metode yang tepat karena metode merupakan dasar pokok dalam penelitian, sehingga dengan adanya metode tersebut dapat diperoleh data yang akurat dan dapat dipertangggung jawabkan.

Metode lebih menekankan pada strategi, pendekatan dan proses dalam memilih karakteristik yang diperlukan. Menurut I Made Wirartha (2006: 76) berpendapat bahwa "metode adalah cara atau jalan untuk mencapai sasaran atau tujuan dalam pemecahan suatu permasalahan”.

Dengan demikian yang dimaksud dengan metode deskriptif korelasional adalah suatu metode penelitian yang digunakan untuk memecahkan suatu masalah, ada atau tidaknya kekuatan hubungan antara satu variabel dengan variabel yang lainnya, jika ada hubungan maka seberapa besar tingkat hubungan variabel tersebut.

Dalam penelitian ini menggunakan desain penelitian deskriptif, yaitu "berkaitan dengan pengumpulan data untuk memberikan gambaran atau penegasan suatu konsep atau gejala, juga menjawab pertanyaan-pertanyaan sehubungan dengan status subyek penelitian pada saat ini”. (I Made Wirartha, 2006: 154)

Jadi dari penjelasan diatas dapat disimpulkan bahwa desain penelitian dapat digu- 
nakan untuk mempermudah untuk menggambarkan atau menegaskan suatu kosep serta dapat menjawab tentang apa yang diteliti.

Rancangan penelitian dapat dilihat pada gambar sebagai berikut:

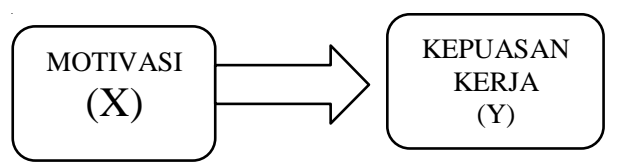

Dalam penelitian

Untuk mendapatkan data yang diperlukan dalam penelitian ini, digunakan teknik pengumpulan data, yaitu:

1. Wawancara

Menurut Nana Syaodih (2007: 216) “wawancara dilaksanakan secara lisan dalam pertemuan tatap muka secara individual. Adakalanya juga wawancara dilakukan secara kelompok”. Wawancara dalam hal ini digunakan untuk mengetahui gambaran secara umum tentang KPRI "Pertaguma" Kota Madiun.

2. Angket atau kuesioner

"Kuesioner, yaitu pengumpulan data penelitian pada kondisi tertentu kemungkinan tidak memerlukan kehadiran peneliti”. (Gabriel Amin, 2003: 81)

Sedangkan menurut Nana Syaodih (2007: 219) "angket atau kuesioner (questionnaire) merupakan suatu teknik atau cara pengumpulan data secara tidak langsung (peneliti tidak langsung betanya-tanya dengan responden). Instrumen atau alat pengumpulan datanya juga disebut angket berisi sejumlah pertanyaan atau pertanyaan yang harus dijawab atau direspon oleh semua responden".

\section{Populasi dan Sampel penelitiaan}

"Populasi memiliki arti seluruh subjek di dalam wilayah penelitian dijadikan subjek penelitian”. (I Made Wirartha, 2006: 231)

Sedangkan Suharsimi Arikunto (2002: 108) mengatakan bahwa "populasi adalah keseluruhan subjek penelitian.

Yang dimaksud populasi diatas yaitu jumlah seluruh karyawan yang ada di KPRI
"Pertaguma” Kota Madiun dengan jumlah populasi dalam penelitian ini adalah 17 karyawan.

Suharsimi Arikunto (2002: 109) menyatakan bahwa "sampel adalah sebagian atau wakil populasi yang diteliti”. Penelitian ini merupakan penelitian populasi sebab semua anggota populasi dijadikan subjek sampel yang berjumlah 17 karyawan.

\section{HASIL PENELITIAN}

\section{Variabel Motivasi}

Dari hasil pengujian statistik deskriptif di atas dapat diketahui bahwa variabel motivasi kerja dengan jumlah total dan standar deviasi sebesar dengan jumlah responden sebanyak 17 diketahui statistik deskriptifnya sebagai berikut: a). Nilai mean sebesar 48,3529; b). Nilai median sebesar 48,0000; c). Nilai modus sebesar 47.00; d). Nilai minimun sebesar 40.00; e). Nilai maksimum sebesar 57.00. Dari analisis deskriptif diatas dapat dikatakan motivasi pada karyawan KPRI "Pertaguma” Kota Madiun, dikatakan baik karena responden yang memperoleh nilai rata-rata e” 48,3529 sebanyak 10 orang atau sebanyak 59\%.

\section{Variabel Kepuasan Kerja}

Dari hasil pengujian statistik deskriptif di atas dapat diketahui bahwa variabel kepuasan kerja dengan jumlah total dan standar deviasi sebesar dengan jumlah responden sebanyak 17 diketahui statistik deskriptifnya sebagai berikut: a). Nilai mean sebesar 47,24; b). Nilai median sebesar 47,00; c). Nilai modus sebesar 47; d). Nilai minimum sebesar 34; e). Nilai maksimum sebesar 57. Dari analisis deskriptif diatas dapat dikatakan kepuasan kerja pada karyawan KPRI "Pertaguma” Kota Madiun, dikatakan baik karena responden yang memperoleh nilai rata-rata $\geq 47,24$ sebanyak 10 orang atau sebanyak $59 \%$.

Atas dasar hasil uji F dapat diketahui nilai $\mathrm{F}_{\text {hitung }}$ sebesar 64,792 sedangkan nilai $\mathrm{F}_{\text {tabel }}$ sebesar 4,54. Dilain pihak nilai Sig $_{\text {hit }}$ sebesar 0,000 dan Sig ${ }_{\text {prob }}$ sebesar 0,05. Hal ini berarti 
bahwa nilai $F_{\text {hitung }} \geq F_{\text {tabel }}(64,792 \geq 4,54)$ dan Sig ${ }_{\text {hit }} \leq \operatorname{Sig}_{\text {prob }}(0,000 \leq 0,05)$. Hal ini dapat dikatakan bahwa $\mathrm{H}_{0}$ ditolak, artinya ada pengaruh motivasi dengan kepuasan kerja pada karyawan KPRI “Pertaguna” Kota Madiun.

Selain digunakan untuk mencari pengaruh uji Fisher atau Anova ini digunakan untuk uji linearitas. Karena $\mathrm{F}_{\text {hitung }}$ sebesar 64,792 $\geq$ $\mathrm{F}_{\text {tabel }}$ sebesar 4,45. Yang artinya ada hubungan yang linear antar dua variabel motivasi dan kepuasan kerja.

Dari uji t diperoleh nilai $t_{\text {hitung }}$ sebesar $8,049 \geq \mathrm{t}_{\text {tabel }}$ sebesar 2,131 atau nilai Sig $_{\text {hit }}$ sebesar $0,000 \leq \operatorname{Sig}_{\text {prob }} 0,05$. Hal ini berarti nilai $\mathrm{t}_{\text {hitung }} \leq \mathrm{t}_{\text {tabel }}(8,049 \geq 2,131)$ atau $\mathrm{Sig}_{\text {hit }} \leq$ $\operatorname{Sig}_{\text {prob }}(0,000 \leq 0,05)$. Dari hasil uji t tersebut dapat dikatakan bahwa $\mathrm{H}_{0}$ ditolak artinya ada beda pengaruh motivasi dengan kepuasan kerja pada karyawan KPRI "Pertaguna” Kota Madiun.

Lebih lanjut apabila dilihat dalam persamaan regresi diperoleh persamaan nilai $\mathrm{Y}=$ $11,203+1,209$. Dari persamaan garis regresi tersebut dapat dilihat jika motivasi meningkat sebanyak 1\% kepuasan kerja akan meningkat pula sebesar 1,209\%, sedangkan faktor lainnya tetap.

\section{Simpulan Hasil Analisis}

Dari hasil analisis data yang dilakukan dalam penelitian ini diambil simpulan sebagai berikut :

\section{Simpulan Uji Fisher}

Dari hasil analisis data untuk uji Fisher dalam penelitian ini dapat diperoleh hasil nilai $F_{\text {hitung }}$ sebesar 64,792 sedangkan nilai $F_{\text {tabel }}$ sebesar 4,54. Dilain pihak nilai Sig ${ }_{\text {hit }}$ sebesar 0,000 dan Sig ${ }_{\text {prob }}$ sebesar 0,05. Hal ini berarti bahwa nilai $\mathrm{F}_{\text {hitung }} \geq \mathrm{F}_{\text {tabel }}(64,792 \geq 4,54)$ dan $\operatorname{Sig}_{\text {hit }} \leq \operatorname{Sig}_{\text {prob }}(0,000$ d” 0,05).

Dengan demikian dapat disimpulkan bahwa $\mathrm{H}_{0}$ ditolak, artinya motivasi memiliki pengaruh terhadap kepuasan kerja pada karyawan KPRI "Pertaguna” Kota Madiun.

\section{Simpulan Koefisien Regresi (Uji t)}

Dari hasil analisis koefisien regresi atau uji $t$ diperoleh nilai $t_{\text {hitung }}$ sebesar 8,049 $\geq t_{\text {tabel }}$ sebesar 2,131 atau nilai Sig $_{\text {hit }}$ sebesar 0,000 $\leq$ Sig $_{\text {prob }} 0,05$. Hal ini berarti nilai $t_{\text {hitung }} \geq t_{\text {tabel }}$ $(8,049 \geq 2,131)$ atau $\operatorname{Sig}_{\text {hit }} \leq \operatorname{Sig}_{\text {prob }}(0,000 \leq$ 0,05). Disimpulkan bahwa ditolak, artinya motivasi memiliki beda pengaruh terhadap kepuasan kerja pada karyawan KPRI “Pertaguna” Kota Madiun.

Lebih lanjut apabila dilihat dalam persamaan regresi diperoleh persamaan $\mathrm{Y}=11,203$ +1 ,209X. Dengan demikian dapat disimpulkan dari persamaan tersebut adalah motivasi meningkat $1 \%$, maka kepuasan kerja akan naik sebesar 1,209\%, dengan faktor lain dianggap tetap.

\section{PEMBAHASAN}

Hasil dari penelitian ini menyatakan bahwa motivasi mempunyai pengaruh terhadap kepuasan kerja pada karyawan. Yang artinya motivasi yang tinggi dari para karyawan dapat memberikan kepuasan kerja terhadap hasil yang dicapainya. Karena kepuasan merupakan hasil yang dirasakan dan hasil dari setiap kali kerja yang dilakukan selama pekerjaan berlangsung.

Pembahasan untuk penelitian ini menggunakan uji Fisher, dan uji t adalah sebagai berikut.

\section{Pembahasan Uji Fisher}

Untuk uji Fisher diperoleh nilai $F_{\text {hitung }}$ $(64,792) \geq F_{\text {tabel }}(4,54)$ atau $\operatorname{Sig}_{\text {hit }}(0,000) \leq$ $\operatorname{Sig}_{\text {prob }}(0,05)$. Dengan hal ini ditolak, artinya ada pengaruh motivasi terhadap kepuasan kerja pada karyawan KPRI "Pertaguna” Kota Madiun.

\section{Pembahasan Uji t}

Dapat dilihat dari hasil persamaan regresi $\mathrm{Y}=11,203+1,209 \mathrm{X}$ sedangkan untuk uji $\mathrm{t}$ diperoleh nilai $t_{\text {hitung }}(8,049)$ e" $\left.t_{\text {tabel }} 2,131\right)$ atau $\operatorname{Sig}_{\text {hit }}(0,000) \leq \operatorname{Sig}_{\text {prob }}(0,05)$. Dengan hal ini 
ditolak, artinya ada beda pengaruh motivasi terhadap kepuasan kerja pada karyawan KPRI "Pertaguna” Kota Madiun.

Motivasi merupakan pendorong bagi pekerjaan seseorang kearah tujuan tertentu dan melibatkan berbagai kemampuan yang dimiliki untuk mencapai kepuasan yang diinginkan. Oleh sebab itu, kepuasan dari seseorang tergantung pada motivasi dari dirinya maupun dari seseorang terhadap suatu pekerjaan yang dikehendakinya.

Adapun tujuan motivasi menurut (Malayu Hasibuan, 2008: 146) antara lain: meningkatkan moral dan kepuasan kerja karyawan, meningkatkan produktivitas kerja karyawan, mempertahankan kestabilan karyawan perusahaan. Semakin tinggi motivasi dari seseorang untuk melakukan suatu pekerjaannya, maka akan semakin tinggi pula kepuasan kerja yang dirasakan.

\section{PENUTUP}

\section{Simpulan}

Motivasi pada karyawan KPRI "Pertaguma” Kota Madiun adalah baik. Hal ini juga dapat terlihat pada keadaan di koperasi mengenai motivasi yang timbul dari dalam diri individu meliputi keinginan untuk dapat hidup, keinginan untuk memperoleh pengakuan dan kompensasi yang memadai. Adapun motivasi yang timbul dari koperasi adalah keadaan lingkungan kerja, jaminan pekerjaan, serta status dan tanggung jawab mereka dalam bekerja. Keadaan tersebut didukung dengan hasil penelitian yaitu perolehan motivasi dengan data statistik deskriptifnya adalah sebagai berikut: a) Nilai jumlah total skor sebesar 822,00 ; b) Nilai mean 48,3529; c) Nilai median 48,0000; d)Nilai mode 47,00; e) Nilai standar deviasi 4,12221; f) Nilai minimum 40,00; g) nilai maximum 57,00. Dari analisis deskriptif diatas dapat dikatakan motivasi pada karyawan KPRI "Pertaguma” Kota Madiun, dikatakan baik karena responden yang memperoleh nilai ratarata $\geq 48,3529$ sebanyak 10 orang atau sebanyak $59 \%$.
Kepuasan kerja pada karyawan KPRI "Pertaguma Kota Madiun adalah baik. Hal tersebut terbukti dari hasil pekerjaan karyawan yang selalu maksimal karena dengan adanya kondisi dan fasilitas kerja yang memadai. Keadaan tersebut didukung oleh hasil penelitian yaitu perolehan kepuasan kerja dengan data statistik deskriptifnya adalah sebagai berikut: a) Nilai jumlah total skor sebesar 803; b) Nilai mean 47,24; c) Nilai median 47,00; d) Nilai mode 47; e) Nilai standar deviasi 5,529; f) Nilai minimum 34; g) nilai maximum 57. Dari analisis deskriptif diatas dapat dikatakan kepuasan kerja pada karyawan KPRI "Pertaguma” Kota Madiun, dikatakan baik karena responden yang memperoleh nilai ratarata $\geq 47,24$ sebanyak 10 orang atau sebanyak $59 \%$.

Motivasi mempunyai pengaruh terhadap kepuasan kerja pada karyawan KPRI “Pertaguma” Kota Madiun. Karena dengan adanya motivasi dari dari dalam diri individu tinggi, menjadikan karyawan bekerja dengan sungguh-sungguh sehingga kepuasan kerja pun ikut meningkat. Hal ini diperkuat dengan adanya hasil dari penelitian yaitu hasil uji F diperoleh hasil nilai Fisher diperoleh hasil nilai $F_{\text {hitung }}$ sebesar 64,792 $\geq \mathrm{F}_{\text {tabel }}$ sebesar 4,54, atau nilai Sig ${ }_{\text {hit }}$ sebesar 0,000 d" Sig ${ }_{\text {prob }}$ sebesar 0,05 ; dan uji t nilai $t_{\text {hitung }}$ sebesar 8,049 $\geq t_{\text {tabel }}$ sebesar 2,131, atau nilai Sig $_{\text {hit }}$ sebesar 0,000 $\leq$ Sig $_{\text {prob }}$ 0,05. Dari semua uji diatas dapat diambil simpulan bahwa $\mathrm{H}_{0}$ ditolah, artinya motivasi mempunyai pengaruh terhadap kepuasan kerja, khususnya pada karyawan KPRI "Pertaguma” Kota Madiun.

\section{Saran}

\section{Bagi Koperasi}

Selain memperhatikan para karyawannya setidaknya atasan juga memperhatikan alatalat yang dapat mendukung kerja dari para karyawan agar dapat menjalankan pekerjaanya dengan baik dan cepat. Serta memberikan fasilitas yang layak dan kondisi lingkungan yang kondusif agar karyawan dapat bekerja dengan nyaman. 


\section{Bagi Karyawan}

Diharapka karyawan pada koperasi dapat terus meningkatkan motivasi dirinya dalam berkerja untuk mencapai rasa kepuasan dalam bekerja. Supaya koperasi tempatnya bekerja dapat berkembang dan dapat memperbesar unit usahanya.

\section{Bagi Peneliti Mendatang}

Untuk memperoleh hasil yang lebih akurat, penulis menyarankan kepada peneliti selanjutnya untuk menggunakan alat analisis yang lebih spesifik, misalnya menggunakan regresi linier dengan menggunakan lebih dari satu variabel-variabel bebas. Dengan demikian, akan dapat diketahui faktor-faktor yang paling berpengaruh terhadap kepuasan kerja.

\section{DAFTAR PUSTAKA}

Ambar Teguh Sulistiyani dan Rosidah. 2003. Manajemen Sumber Daya Manusia. Yogyakarta: Graha Ilmu.

Edy Sutrisno. 2010. Manajemen Sumber Daya Manusia. Jakarta: Kencana Prenada Media Group.

Gabriel Amin Silalahi. 2003. Metodologi Penelitian dan Studi Kasus. Wage Taman Sidoarjo: CV. Citra Media.
Hani Handoko, T. 2011. Manajemen Personalia \& Sumber Daya Manusia Edisi 2. Yogyakarta: BPFE-Yogyakarta.

Hendrojogi. 2007. Koperasi: Asas-asas, Teori, dan Praktik. Jakarta: PT. RajaGrafindo Persada.

I Made Wirartha. 2006. Metodologi Penelitian Sosial Ekonomi. Yogyakarta: CV. Citra Medika.

Indriyo Gitosudarmo dan Agus Mulyono. 2001. Prinsip Dasar Manajemen Edisi 3. Yogyakarta: BPFE-Yogyakarta.

Malayu S.P Hasibuan. 2008. Manajemen Sumber Daya Manusia Edisi Revisi. Jakarta: PT. Bumi Aksara.

Marihot Amh Manullang. 2006. Manajemen Personalia. Yogyakarta: Gajah Mada University Press.

Nana Syaodih Sukmadinata. 2007. Metode Penelitian Pendidikan. Bandung: PT. Remaja Rosdakara.

Suharsimi Arikunto. 2002. Prosedur Penelitian Suatu Pendekatan Praktek Edisi Revisi V. Jakarta: PT. Rineka Cipta.

Terry, George R. 2012. Prinsip-prinsip Manajemen. Jakarta: PT. Bumi Aksara.

Wilson Bangun. 2012. Manajemen Sumber Daya Manusia. Erlangga. 